\title{
Spatial heterogeneity of the planktonic fields in the upper mixed layer of the open ocean
}

\author{
S. A. Piontkovski ${ }^{1}$, R. Williams ${ }^{2, *}$, W. T. Peterson ${ }^{3}$, O. A. Yunev ${ }^{1}$, N. I. Minkina ${ }^{1}$, \\ V. L. Vladimirov ${ }^{4}$, A. Blinkov ${ }^{1,4}$ \\ ${ }^{1}$ Institute of Biology of the Southern Seas, 335011 Sevastopol, Ukraine \\ ${ }^{2}$ Plymouth Marine Laboratory, Prospect Place, Plymouth PL1 3DH, United Kingdom \\ ${ }^{3}$ Hatfield Marine Science Center, 2030 Marine Science Drive, Newport, Oregon 97365, USA \\ ${ }^{4}$ Marine Hydrophysical Institute, 2 Kapitanskaya Str., 335000 Sevastopol, Ukraine
}

\begin{abstract}
Field surveys were conducted in the open ocean regions of the Indian and Atlantic Oceans and the Mediterranean (Adriatic) Sea. Continuous records were taken along transects of several hundreds of $\mathrm{km}$ over the area. Zooplankton and chlorophyll a (chl a) samples were collected from the surface layer using a high capacity pump while the ship was underway. The quantitative trends of occurrence of zooplankton biomass of different patch sizes over the studied areas were quite similar. From the averaged trend and non-linear regression analysis, it was demonstrated that on a scale of tens to hundreds of $\mathrm{km}$ the number of patches exponentially diminishes with patch size. The power spectra of temperature, chl a and zooplankton biomass in the surface layer were similar They monotonically decrease with the decrease of the spatial wavelength of oscillations of the above parameters. The typical slope of the spectra of temperature, phytoplankton and zooplankton fields are within the range of -3 to -2 in a band of wavelengths from 200 to $10 \mathrm{~km}$. In the western subtropical Atlantic where the internal waves are well developed in the seasonal thermocline layer, the variability of zooplankton biomass was characterised by a power spectra having several local peaks of spatial spectral density on a background of a declining curve. Nevertheless, the average spectra slope exhibits the same trend, that is, it diminishes with the slope of the curve within the range -3 to -2 . Temperature and zooplankton biomass spectra exhibited coherent local peaks of spectral density at similar wavelengths.
\end{abstract}

KEY WORDS: Zooplankton $\cdot$ Spatial heterogeneity $\cdot$ Atlantic Ocean

\section{INTRODUCTION}

For more than 100 yr spatial-temporal variations of plankton abundance and biomass have been researched. One reason for this is that the spatial heterogeneity of a plankton community structure is a fundamental feature defining patterns of population dynamics within ecosystem trophic webs (Le Brasseur et al. 1969, Lasker 1976, Lasker \& Zweifel 1978). The development of our understanding of the spatial heterogeneity of plankton distribution in the ocean has been a subject of several reviews (Cassie 1963, Haury et al. 1978, Steele

\footnotetext{
·Addressee for correspondence. E-mail: bw@wpo.nerc.ac.uk
}

1978, Longhurst 1981, Horne \& Platt 1984, Mackas et al. 1985, Haury \& Pieper 1988). This development has been achieved essentially through reductionist and holistic approaches. The reductionist view has led to studies of morphology of plankton patches, their form, dimensions and density of packing in space in relation to various environmental factors (e.g. Cushing \& Tungate 1963, Boyd 1973, Hamner \& Carleton 1979, Omori \& Hamner 1982, Alldredge et al. 1984). The supporters of the holistic approach have studied properties of the whole spatially heterogeneous field of a parameter, preferring to analyse planktonic fields in terms of continuous structures by means of appropriate statistical methods of spectral analysis, correlation functions, etc. (e.g. Platt \& Denman 1975, Fasham 1978a, b, Herman et al. 1981). Both ways of thinking have contributed 
innovative ideas to our understanding of plankton patchiness.

Both approaches were used in this study to elucidate some general trends in the spatial heterogeneity of plankton fields of the tropical ocean on a scale of tens to hundreds of $\mathrm{km}$ in an attempt to quantify the patchiness and to discuss factors governing its formation. Information on spatial heterogeneity of planktonic fields from shelf zones has been published previously but, until now, was lacking for the open ocean regions on such a large scale.

Our studies were confined to the upper mixed layer of the ocean for several reasons. Firstly, methods of high-frequency plankton sampling, when a vessel is underway, have been developed mostly for this particular layer. Secondly, in the tropical latitudes of the Atlantic and Indian Oceans and the Mediterranean Sea the major part of the phyto- and zooplankton biomass is concentrated in the upper mixed layer (Greze et al. 1984, Piontkovski et al. 1985b). Finally, assessment of the spatial heterogeneity of the upper layer has become important during the last few years, in parallel with the development of remote sensing methods and the programs of the global ocean observing systems (Platt et al. 1991, Aiken et al. 1992, IOC 1992). The satellite sensors are used to scan the upper layer of the ocean, whereby biological patterns can be observed and quantified. This requires detailed knowledge of the spatial structure of optical, physical and biological fields for regions which differ geographically and in their productivity. In this respect the open ocean, in a scale range from tens to hundreds of $\mathrm{km}$, is still poorly known. The algorithms currently used to reconstruct the chlorophyll a $(\mathrm{chl}$ a) fields from remotely sensed colour data for the open ocean regions are still, in the main, unsustainable and rough, because of a lack of validated field data.

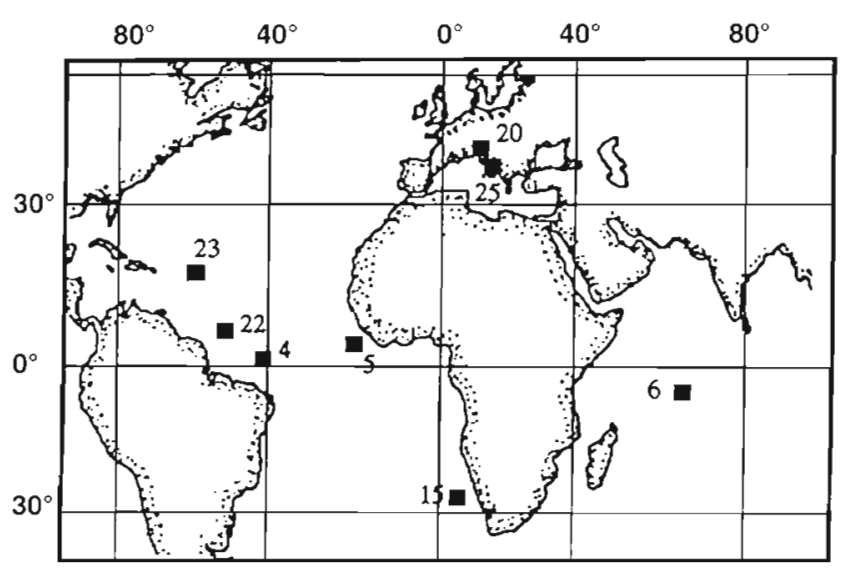

Fig. 1 Positions of the sampling areas

\section{METHODS}

Sampling. Field surveys were conducted in the open ocean regions of the Indian and Atlantic Oceans and the Mediterranean (Adriatic) Sea (Fig. 1, Table 1) during expeditions of Ukrainian research vessels (1982 to 1984) targeted to study the water dynamics and ecosystems of the oligotrophic and mesotrophic waters of the open ocean in the mostly poorly investigated areas of the world's ocean. To study spatial heterogeneity as a stochastic process, statistically sustainable data are required. We have selected the method of continuous sampling in the upper layer as the basic element in assessment of patchiness along transects of several hundreds of $\mathrm{km}$ over the sampled areas.

Zooplankton samples were collected every $15 \mathrm{~min}$ from the surface layer, between 2 and $6 \mathrm{~m}$, using a high capacity pump (200 I $\left.\mathrm{min}^{-1}\right)$ while the ship was underway. The applicability of pumps in studies of plankton distributions from the upper layer has been well documented (Aron 1958), and good results in assessments of the mesoscale spatial heterogeneity (De Decker 1984) can be obtained. In our case, water was filtered for $15 \mathrm{~min}$ into collecting elements ranging in mesh size from 112 to $145 \mu \mathrm{m}$. Thus, we were operating with the biomass or numerical abundance of zooplankton organisms averaged over $5 \mathrm{~km}$ intervals. The wet weight of samples was obtained on board by means of a balance (WT-500, precision $\pm 0.1 \mathrm{mg}$ ) after which samples were preserved in $4 \%$ formalin. De-

Table 1. Transect positions of zooplankton continuous records

\begin{tabular}{|c|c|c|c|c|}
\hline Transect & & Latitude & Longitude & Month/year \\
\hline \multicolumn{5}{|c|}{ Indian Ocean } \\
\hline 6 & $\begin{array}{l}\text { From } \\
\text { to }\end{array}$ & $\begin{array}{l}2^{\circ} 00^{\prime} \mathrm{S} \\
9^{\circ} 00^{\prime} \mathrm{S}\end{array}$ & $\begin{array}{l}62^{\circ} 00^{\prime} \mathrm{E} \\
62^{\circ} 00^{\prime} \mathrm{E}\end{array}$ & Jan 1983 \\
\hline \multicolumn{5}{|c|}{ Atlantic Ocean } \\
\hline 4 & $\begin{array}{l}\text { From } \\
\text { to }\end{array}$ & $\begin{array}{r}12^{\circ} 00^{\prime} \mathrm{N} \\
8^{\circ} 00^{\prime} \mathrm{N}\end{array}$ & $\begin{array}{l}30^{\circ} 00^{\prime} \mathrm{W} \\
35^{\circ} 00^{\prime} \mathrm{W}\end{array}$ & Aug 1982 \\
\hline 22 & $\begin{array}{l}\text { From } \\
\text { to }\end{array}$ & $\begin{array}{l}3^{\circ} 00^{\prime} \mathrm{N} \\
9^{\circ} 00^{\prime} \mathrm{N}\end{array}$ & $\begin{array}{l}45^{\circ} 40^{\prime} \mathrm{W} \\
51^{\circ} 20^{\prime} \mathrm{W}\end{array}$ & Aug-Sep 1984 \\
\hline 23 & $\begin{array}{l}\text { From } \\
\text { to }\end{array}$ & $\begin{array}{l}10^{\circ} 00^{\prime} \mathrm{N} \\
12^{\circ} 00^{\prime} \mathrm{N}\end{array}$ & $\begin{array}{l}56^{\circ} 00^{\prime} W \\
56^{\circ} 00^{\prime} W\end{array}$ & Sep 1982 \\
\hline 5 & $\begin{array}{l}\text { From } \\
\text { to }\end{array}$ & $\begin{array}{r}10^{\circ} 00^{\prime} \mathrm{N} \\
8^{\circ} 13^{\prime} \mathrm{N}\end{array}$ & $\begin{array}{l}17^{\circ} 00^{\prime} \mathrm{W} \\
17^{\circ} 00^{\prime} \mathrm{W}\end{array}$ & Oct 1982 \\
\hline 15 & $\begin{array}{l}\text { From } \\
\text { to }\end{array}$ & $\begin{array}{l}8^{\circ} 52^{\prime} \mathrm{N} \\
7^{\circ} 30^{\prime} \mathrm{N}\end{array}$ & $\begin{array}{ll}0^{\circ} 31^{\prime} \mathrm{W} \\
0^{\circ} 05^{\prime} \mathrm{W}\end{array}$ & Jan 1982 \\
\hline \multicolumn{5}{|c|}{ Adriatic Sea } \\
\hline 20 & $\begin{array}{l}\text { From } \\
\text { to }\end{array}$ & $\begin{array}{l}38^{\circ} 58^{\prime} \mathrm{N} \\
44^{\circ} 21^{\prime} \mathrm{N}\end{array}$ & $\begin{array}{l}19^{\circ} 55^{\prime} \mathrm{W} \\
12^{\circ} 40^{\prime} \mathrm{W}\end{array}$ & Mar 1982 \\
\hline 25 & $\begin{array}{l}\text { From } \\
\text { to }\end{array}$ & $\begin{array}{l}38^{\circ} 58^{\prime} \mathrm{N} \\
44^{\circ} 21^{\prime} \mathrm{N}\end{array}$ & $\begin{array}{l}19^{\circ} 55^{\prime} \mathrm{W} \\
12^{\circ} 40^{\prime} \mathrm{W}\end{array}$ & Apr 1982 \\
\hline
\end{tabular}


tailed zooplankton analysis of selected samples was conducted back in the laboratory. It was concluded from our studies and previous information (Aron 1958, Miller \& Judkins 1981) that the loss of organisms due to pump damage did not exceed $15 \%$

Temperature and chl a measurements were taken simultaneously with zooplankton on certain transects. Chl a values were determined on the basis of fluorescence analysis from 31 of sea water. A sample of water was taken every 15 min (i.e. point measurements). The concentration of chl a was calculated from the equation of Gibbs (1979).

Temperature was continuously measured at the surface ( 2 to $4 \mathrm{~m}$ depth) using a towed temperature sensor 'MHI-4203' (precision $\pm 0.01^{\circ} \mathrm{C}$ ). An undulating temperature recorder was used during Transect 22 to obtain continuous records of temperature in the thermocline layer $(40$ to $70 \mathrm{~m}$ ) in order to assess the parameters of the internal gravity waves.

Due to the different aims of the separate expeditions, it was not possible to carry out the same suite of field measurements on the spatial heterogeneity through all the studied regions. On Transects 6, 15, 20 and 25 only zooplankton continuous records were collected, while on Transects 4, 5, 22 and 23 simultaneous zooplankton and temperature records were taken. Temperature was measured within the thermocline layer (Transect 22) or in the surface layer (Transect 23). Transect 22 included several sub-transects (S1 to S7) Transects 4 and 5 had simultaneous temperature, chl $a$ and zooplankton records measured in the surface layer.

CTD 'Istok' (with a temperature sensitivity of $0.0025^{\circ} \mathrm{C}$, a measurements error of $0.001^{\circ} \mathrm{C}$, and a time lag for the sensor about $50 \mathrm{~ms}$ ) was used for vertical profiling. The specific electrical conductivity was 1.3 to $7.0 \mathrm{~cm} \mathrm{~m}^{-1}$, the sensitivity was $0.0025 \mathrm{~cm} \mathrm{~m}^{-1}$ with a measurement error of $0.002 x$ (where $x$ is the conductivity number). The hydrostatic pressure was estimated by means of the pressure sensor with a band of 0 to $60 \mathrm{MPa}$ (0 to $6000 \mathrm{dbar}$ ), a sensitivity of 0.004 to 0.007 MPa and a measurement error of $0.25 \%$.

The submersible device for the current velocity measurements had the following characteristics: the measurement band was from -3 to $3 \mathrm{~m} \mathrm{~s}^{-1}$ with a sensitivity of $4 \mathrm{~mm} \mathrm{~s}^{-1}$ and a measurement error of $(1-4 \mathrm{~V}) \times 10^{-2}$ $\mathrm{m} \mathrm{s}^{-1}$ (where $V$ is the measured velocity of a current)

Beside measurements taken onboard, longer-term temperature records were also conducted from a buoy station. Long time series of temperature and the direction and velocity of currents were recorded by means of the autonomous sensors 'DISK', where impeller-type sensors were mounted to measure the currents in a range from 0 to $1.8 \mathrm{~m} \mathrm{~s}^{-1}$, with a sensitivity of $7 \mathrm{~mm} \mathrm{~s}^{-1}$. Current and temperature sensors were distributed vertically at $25,50,75,100,150,200,300,500,750,1000$ and $1500 \mathrm{~m}$. Measurements were taken from each depth horizon for $17 \mathrm{~d}$ with a temporal resolution of 5 min. Data were stored within the submersible modules. Detailed descriptions of the above hydrographic equipment can be found in Bulgakov et al. (1991).

Data analysis. Because the transect surveys took several days, the effects of diel vertical migration on the estimates of zooplankton biomass were corrected using the following procedure. The day was divided into twelve $2 \mathrm{~h}$ periods and all biomass values were assigned to their appropriate periods. The averaged biomass was calculated for each of the twelve 2 h periods. The obtained trend was removed from the initial field data when the horizontal spatial heterogeneity was analysed, i.e. $B_{\mathrm{p}}=B_{\|}-\mathrm{B}^{\wedge}{ }_{t}$, where $B_{\mathrm{p}}$ is the detrended pure pulsative number of zooplankton biomass, $B_{l j}$ is the current biomass number $j$ from the data spatial record obtained at time $j$, and $B^{\wedge}$ is the averaged biomass at time $t$ (i.e. average for the given $2 \mathrm{~h}$ period). Typical trend curves have been considered earlier for different regions (Piontkovski \& Goldberg 1984, Piontkovski et al. 1985b, c).

Following this procedure of removing the main temporal trend, the zooplankton biomass distribution in space was represented in the form of deviations from the mean along a transect. (Fig. 2). Deviations were interpreted as spatial heterogeneities or patches (Wiebe 1970, Goldberg \& Piontkovski 1985), and the frequency of occurrence of heterogeneities of different spatial size were estimated. In this study it is assumed that when a patch of zooplankton biomass (or species abundance) is encountered, the zooplankton biomass distribution exceeds 1 SD.

Spectral and regression analysis (Konyaev 1981) were used to represent biomass fluctuations along transects, and the contribution of various scale components to the variability of parameters was assessed. In

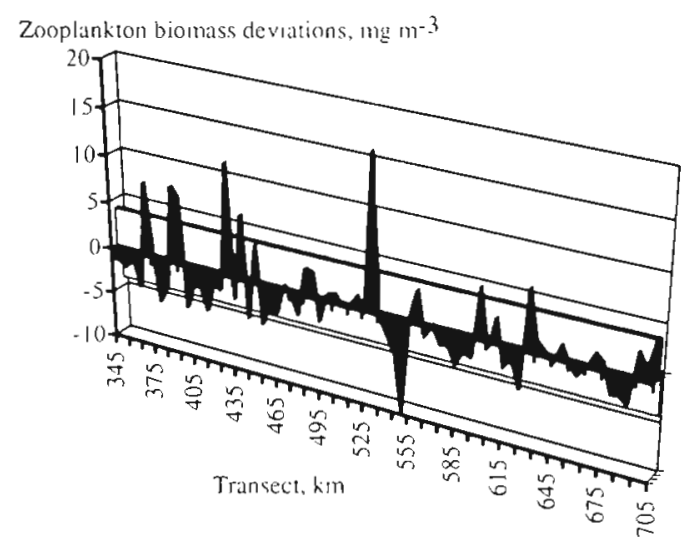

Fig. 2. Zooplankton biomass deviations along part of Transect 22 . Semi-diel rhythms were de-trended from the continuous record data 
the case of the Fast Fourier Transform (FFT) spectra the $95 \%$ confidence intervals were calculated. When using the regression models of the power spectra the assessments of the variance $\left(S^{2}\right)$ of the useful signal and the noise were calculated for the zooplankton power spectra. These values are represented in the form of signal/noise ratios (see Table 2).

\section{RESULTS}

\section{Hydrological peculiarities of studied regions}

Transects 4 and 22 (Atlantic Ocean) were performed in different years in the same region during autumn. The Interpassat Counter-Current (ICC) was the major element of the macroscale geostrophical circulation, ensuring about $80 \%$ of the water mass transport (40 to 50 sverdrups; $\mathrm{sv}=10^{6} \mathrm{~m}^{3} \mathrm{~s}^{-1}$ ) through this area in the autumn (Polonski et al. 1985). Typical current velocity was 60 to $80 \mathrm{~cm} \mathrm{~s}^{-1}$ in the upper layer in the autumn
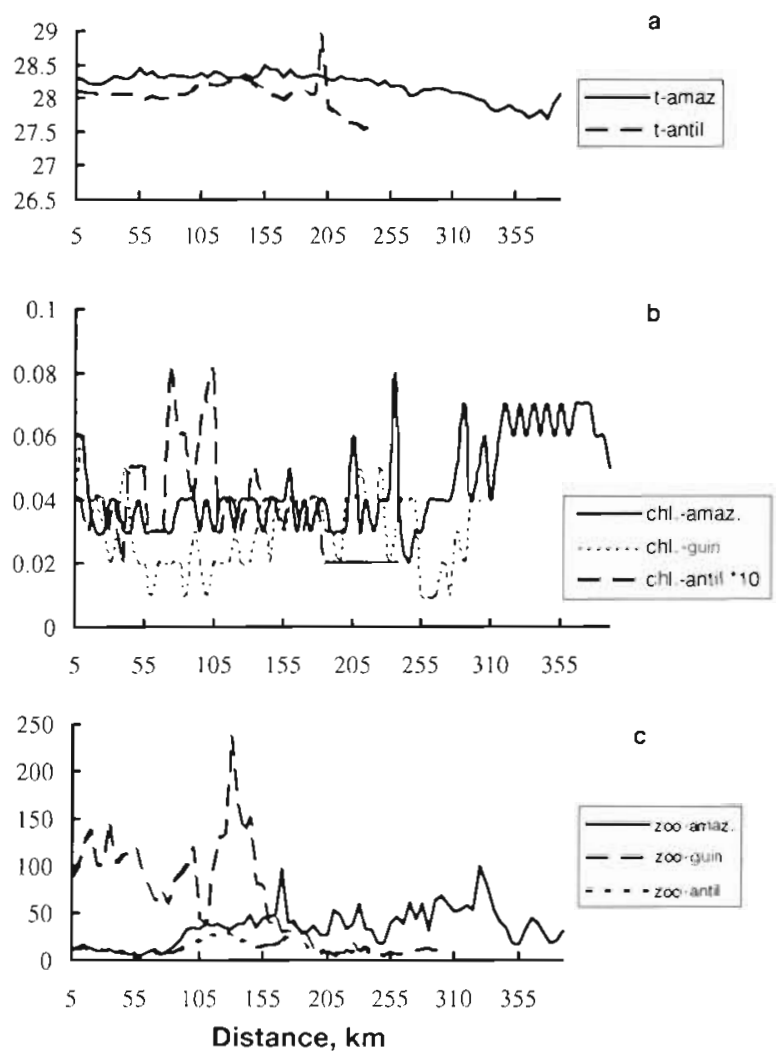

Fig. 3. Examples of (a) the upper layer temperature $\left({ }^{\circ} \mathrm{C}\right)$, (b) chl a ( $\mathrm{mg} \mathrm{m}^{-3}$ ) and (c) zooplankton biomass ( $\mathrm{mg} \mathrm{m}^{-3}$ ) records along Transects 4 (Amazonian transect), 23 (Antillean transect) and 5 (Guinean transect). Data are not de-trended (i.e. they carry spatial and temporal components of variability). Numbers on the horizontal axis indicate the distance from the beginning of the records and winter periods. Vertically, the velocity declined with depth to $20 \mathrm{~cm} \mathrm{~s}^{-1}$ at $400 \mathrm{~m}$. The thickness of the mixed layer varied from 20 to $100 \mathrm{~m}$.

Transect 23 (Atlantic Ocean) was executed in the region of the convergent waters of the Caribbean basin, where the mixed layer was deeper at depths of 70 to $120 \mathrm{~m}$. These were the most oligotrophic waters of all the studied areas, with a chl a concentration of about 0.004 to $0.006 \mathrm{mg} \mathrm{m}^{-3}$ in the upper layer.

Transect 5 (Atlantic Ocean) was conducted in waters of the ICC, which contributes about $70 \%$ of the total mass transport in the upper $200 \mathrm{~m}$ in the given region (Artamonov et al. 1987). The upper layer was occupied by the Equatorial Water Mass (EWM), with a temperature of $<29.2^{\circ} \mathrm{C}$ and a salinity of $34.5 \%$. The position of the EWM corresponded to that of the ICC and the Intertropical Convergence Zone. The mixed layer was well developed and penetrated to depths of $40 \mathrm{~m}$.

Transect 15 (Atlantic Ocean) was performed in waters of the south tropical cyclonic macroscale gyre (Greze et al. 1984). The well-developed mixed layer penetrated to depths from 20 to $80 \mathrm{~m}$. The seasonal thermocline was well pronounced and had vertical gradients of temperature of 0.3 to $0.4^{\circ} \mathrm{C} \mathrm{m}^{-1}$.

Transects 20 and 25 were conducted one after another, with a temporal interval of about 4 wk, along the entire length of the Adriatic Sea. The upper layer was well mixed down to $700 \mathrm{~m}$ in March and April, as the surveys were carried out after intensive winter mixing by gales. The whole water layer, from the surface to $700 \mathrm{~m}$ had a temperature of about $8^{\circ} \mathrm{C}$ (in the northwestern part) and a salinity of $38.7 \%$ (Ovchinnikov et al. 1985). The current velocities measured in the southern part of the transects were $8 \mathrm{~cm} \mathrm{~s}^{-1}$ at the surface.

Transect 6 (Indian Ocean) was executed in waters of the northeast Monsoon Current, which penetrated to a depth of $100 \mathrm{~m}$ in this region (Plotnikov 1986). The latitudinal geostrophical velocity of the current was $25 \mathrm{~cm} \mathrm{~s}^{-1}$ The upper layer, with a temperature of 28.0 to $28.6^{\circ} \mathrm{C}$ and a salinity of $35.3 \%$, was occupied by the Equatorial Water Mass. Due to mesoscale eddies causing local upwellings and downwellings, the thickness of the mixed layer varied from 20 to $90 \mathrm{~m}$ on the transect.

\section{Dimensions and occurrence of spatial heterogeneities}

Fragments of the continuous records of temperature, chl $a$ and zooplankton in the upper layer are presented in Fig. 3. Obviously, temperature exhibits the lessdeveloped variability, whereas chl a and especially zooplankton biomass show more substantial variation. 
These variations contain the spatial and temporal components. The latter was most well developed in the zooplankton field variability. It might be noted that in the majority of cases the zooplankton peaks in the continuous records were associated with the nocturnal time periods (19:00 to $21: 00 \mathrm{~h}$ ) or the early morning 105:00 to 07:00 h).

Being conducted in geographically different regions, these transects have enabled us to assess quantitatively the spatial heterogeneity of the planktonic and temperature fields in the upper layer The variation coefficients of zooplankton biomass along transects were: no. $453 \%$; no. $584 \%$; no. $681 \%$; no. $1565 \%$; no. $2052 \%$; no. 22 from 46 to $67 \%$ (over sub-transects); no. $2357 \%$; no. $2558 \%$.

These assessments are valid for the primary data (i.e. including the diel trends) from the transects. The mean biomass of zooplankton in the upper mixed layer was quite similar over the regions (20 to $60 \mathrm{mg} \mathrm{m}^{-3}$ ) and demonstrated the oligotrophic/mesotrophic status of the studied areas.

Sample treatment from the studied regions showed that planktonic Copepoda numerically composed from 75 to $95 \%$ of the organisms in the pump samples. Species composition changed over the studied regions; however, the main taxa remained constant and were represented by the genera Calanus, Calocalanus, Pseudocalanus, Oncaea, Oithona, Pleuromamma and Corycaeus. The individual sizes of organisms were mostly in a range from 0.5 to $2.0 \mathrm{~mm}$. Samples were not sorted to species level on all transects. For Transect 15 all data (118 samples) were treated at species level. The copepods Oncaea ornata and Microsetella rosea were the most numerous species inhabiting the upper layer. No differences in the frequency of occurrence of spatial heterogeneities of biomass and species were found (Fig. 4), although the variation coefficients for $O$. ornata and $M$. rosea abundance along the transect were 1.5 times higher than that of the integrated zooplankton biomass. The individual data points in the biomass curve are not well defined because they overlap with those of the species. The quantitative trends of occurrence of patches of zooplankton biomass were similar over the studied areas. An assessment of occurrence of patches was conducted for 5 transects (nos. 6 , $15,20,22$ and 25) and the data amalgamated in a boxand-whiskers plot (Fig. 5). From the averaged trend and non-linear regression analysis it can be shown that on a mesoscale the occurrence of the number of patches $(Y)$ diminishes exponentially with patch size $(X)$ :

$$
Y=5.24 \exp [-(X-5.14) / 13.18)]
$$

Besides the dimensions of patches, the amplitude of biomass deviations can be considered as an important

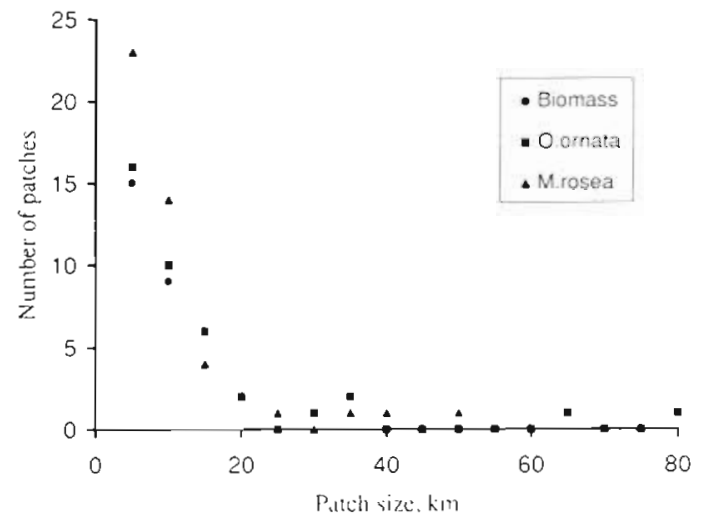

Fig. 4. Frequency of occurrence of integrated zooplankton biomass and the spatial heterogeneities of the 2 most abundant copepod species in the upper layer Orcaea ornata and Microsetella rosa as a function of patch dimensions (Transect 15)

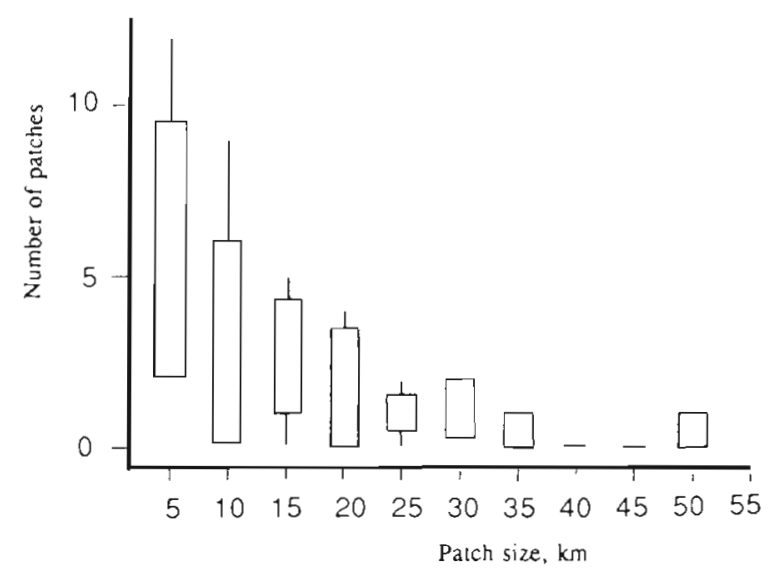

Fig. 5. Frequency of occurrence of spatial heterogeneities of integrated zooplankton biomass from all sampling sites as a function of patch dimensions. Bottom and top of the box are the first and third quartiles, respectively. Whiskers (vertical lines from the box) extend to the lowest and highest values of the parameters

parameter characterising the 'intensity' of spatial heterogeneity. Zooplankton biomass fluctuations along transects were observed up to $30 \mathrm{mg} \mathrm{m}^{-3}$ from the mean. However, no statistically sustainable relationship between the spatial linear dimension of the heterogeneities and the biomass amplitude observed within these heterogeneities was found for heterogeneities in a size range from 10 to $100 \mathrm{~km}$.

\section{Power spectra of planktonic fields}

The spatial spectral density function (the power spectrum) gives an indication of how the density of biomass fluctuations is distributed along the spatial 

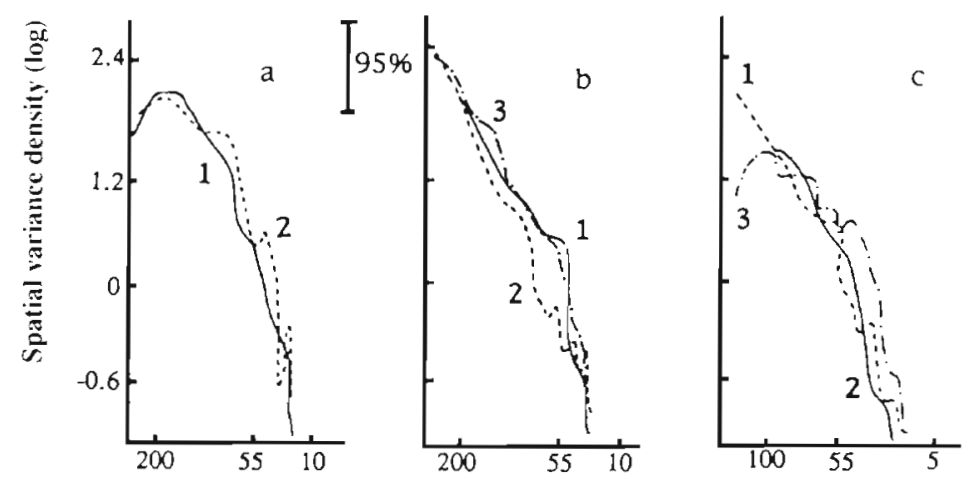

Wavelength of oscillations, $\mathrm{km}$ (log scale)

Fig. 6. Power spectra of temperature, chl a and zooplankton from the sampling sites in the tropical Atlantic (surface layer). The spectra were averaged in a window $\mathrm{n}=5$. The vertical bar shows the confidence interval. (a) Grid 23, (b) Grid 4, (c) Grid 5. 1: Zooplankton biomass (mg $\left.\mathrm{m}^{-3}\right)$; 2 : chl a $\left(\mathrm{mg} \mathrm{m}^{-3}\right)$; 3 : temperature $\left({ }^{\circ} \mathrm{C}\right)$

scale. It also shows the contribution of various scale oscillations of zooplankton biomass along the transects to the total parameter field variance. Simultaneous measurements of temperature, chl a and zooplankton biomass enabled a calculation and comparison of the power spectra of these 3 parameters obtained from transects from 3 sampling grids in the tropical Atlantic Ocean (Fig. 6).

The power spectra of temperature, chl a and zooplankton biomass in the surface layer are similar. They monotonically decrease with the decrease of the spatial wavelength of oscillations of the above parameters. Obviously, spectra do not exhibit any well-defined peaks which could be interpreted as the bands of the dominance of certain spatial heterogeneities with given definite dimensions. The contribution of the various-size heterogeneities to the total spatial variance of a field diminishes proportionally to their spatial size for the wavelength of biomass fluctuations in space). Such a pattern can be observed throughout the various regions of the tropical zone of the ocean. If the $95 \%$ confidence intervals are taken into account, it can be concluded that the typical slope of the spectra of temperature, chl $a$ and zooplankton fields are within the range of -3 to -2 in a band of wavelengths from 200 to $10 \mathrm{~km}$.

Zooplankton continuous records and temperature in the seasonal thermocline, where the internal waves were well developed (Vladimirov et al. 1981), were taken on Transect 22 . The vertical density structure had the following typical features. The upper mixed layer had a thickness of 20 to $25 \mathrm{~m}$ followed by the thermocline with a sharp density gradient. Two maxima of the Brunt-Väisälä frequency, the first one at $25 \mathrm{~m}$ depth $\left(15 \times 10^{-3} \mathrm{rad} \mathrm{s}^{-1}\right)$ and the second at a depth of $90 \mathrm{~m}\left(30 \times 10^{-3} \mathrm{rad} \mathrm{s}^{-1}\right)$, were noted, which corre- sponded to an oscillation period of $3.5 \mathrm{~min}$. Currents in the upper layer ( 30 to $40 \mathrm{~cm} \mathrm{~s}^{-1}$ ) were directed from the northwest to the southeast. From CTD data this current has been identified as the southern limb of the North Passat Current acting in a region of the Interpassat Counter-Current formation. The analysis of records from the buoy station have revealed the intensive fluctuations of currents with a period of about $3 \mathrm{~d}$ in the upper $100 \mathrm{~m}$ layer, where the velocities quickly diminished with depth. Peaks corresponding to the period of the semi-diel tide were also visible. Temperature fluctuations with the same period were registered at depths of 150 to $200 \mathrm{~m}$.

Variability of zooplankton biomass from this survey was characterised by power spectra having several local peaks of spatial spectral density on a background of a declining curve (Table 2). From values of the signal/noise ratios these peaks can be considered as statistically distinguishable. Again, as discussed above, the average spectra slopes exhibit the same trend (i.e. diminishing with the slope of the curve within the range -2 to -3 ). Temperature and zooplankton biomass spectra exhibit coherent local peaks of spectral density at similar wavelengths (see Table 2). Quantitatively the similarity of the statistical structure of the temperature and zooplankton fields is reflected in the relatively high correlation between the averaged spectra slopes of both parameters $(r=0.95, p=0.05)$.

It should be noted that the procedures of the spectral analysis have been applied to the data with the diel trend of zooplankton biomass removed, which excludes the main periodic component. The diel trend usually has both a 12 and $24 \mathrm{~h}$ period in the studied regions (Piontkovski \& Goldberg 1984, Piontkovski et al. $1985 a$, b)

\section{DISCUSSION}

Although data available from literature on zooplankton distributions along transects are quite numerous, they are rarely used for non-linear statistics due to their non-regularity of sampling or short series in space. Such data are nearly absent for the open ocean regions; therefore we have restricted ourselves to data collected on Ukrainian cruises by the same method. This enables data from various regions and years to be collated and compared.

The similarity in functions describing the frequency of occurrence of zooplankton patches from different regions indicates a possible similarity in the mecha- 
Table 2. Characteristics of zooplankton biomass and temperature power spectra peaks and their average slopes according to continuous records data from the tropical Atlantic

\begin{tabular}{|c|c|c|c|c|c|c|c|}
\hline $\begin{array}{l}\text { Subtransects of } \\
\text { Transect } 22\end{array}$ & Parameter & $\begin{array}{r}\text { Os } \\
1 \text { st peak }\end{array}$ & $\begin{array}{l}\text { Illation way } \\
\text { 2nd peak }\end{array}$ & $\begin{array}{l}\text { velength }( \\
\text { 3rd peak }\end{array}$ & $\begin{array}{l}\text { m) } \\
4 \text { th peak }\end{array}$ & $\begin{array}{l}\text { Power spectra } \\
\text { slope }\end{array}$ & $\begin{array}{l}S^{2} \text { signal/S } S^{2} \text { noise } \\
\text { ratio (zooplankton) }\end{array}$ \\
\hline S1 & $\begin{array}{l}\text { Temperature } \\
\text { Zooplankton }\end{array}$ & $\begin{array}{l}148.2 \\
164.6\end{array}$ & $\begin{array}{l}74.1 \\
41.2\end{array}$ & $\begin{array}{l}44.5 \\
35.3\end{array}$ & $\begin{array}{l}22.2 \\
26.0\end{array}$ & $\begin{array}{l}-1.9 \\
-1.7\end{array}$ & 360 \\
\hline $\mathrm{S} 2$ & $\begin{array}{l}\text { Temperature } \\
\text { Zooplankton }\end{array}$ & $\begin{array}{c}222.2 \\
-\end{array}$ & $\begin{array}{l}70.4 \\
38.0\end{array}$ & $\begin{array}{l}37.0 \\
24.7\end{array}$ & $\begin{array}{l}18.5 \\
12.3\end{array}$ & $\begin{array}{l}-3.2 \\
-3.0\end{array}$ & 103 \\
\hline S3 & $\begin{array}{l}\text { Temperature } \\
\text { Zooplankton }\end{array}$ & $\begin{array}{l}222.2 \\
164.6\end{array}$ & $\begin{array}{l}74.1 \\
49.4\end{array}$ & $\begin{array}{l}44.5 \\
35.3\end{array}$ & $\begin{array}{l}18.5 \\
26.0\end{array}$ & $\begin{array}{l}-1.2 \\
-1.5\end{array}$ & 483 \\
\hline $\mathrm{S} 4$ & $\begin{array}{l}\text { Temperature } \\
\text { Zooplankton }\end{array}$ & $\begin{array}{l}111.1 \\
164.6\end{array}$ & $\begin{array}{l}55.6 \\
70.6\end{array}$ & $\begin{array}{l}37.0 \\
44.9\end{array}$ & $\begin{array}{l}- \\
-\end{array}$ & $\begin{array}{l}-2.3 \\
-2.5\end{array}$ & 1017 \\
\hline S5 & $\begin{array}{l}\text { Temperature } \\
\text { Zooplankton }\end{array}$ & $\begin{array}{r}92.6 \\
246.6\end{array}$ & $\begin{array}{r}55.6 \\
123.5\end{array}$ & $-\overline{4} \cdot 9$ & $\begin{array}{l}22.2 \\
15.0\end{array}$ & $\begin{array}{l}-1.6 \\
-1.4\end{array}$ & 330 \\
\hline S6 & $\begin{array}{l}\text { Temperature } \\
\text { Zooplankton }\end{array}$ & $\begin{array}{r}166.7 \\
98.8\end{array}$ & $\begin{array}{l}66.7 \\
44.7\end{array}$ & $\begin{array}{l}37.0 \\
30.9\end{array}$ & $\begin{array}{l}- \\
-\end{array}$ & $\begin{array}{l}-1.9 \\
-1.9\end{array}$ & 489 \\
\hline S7 & $\begin{array}{l}\text { Temperature } \\
\text { Zooplankton }\end{array}$ & $\begin{array}{l}160.5 \\
167.9\end{array}$ & $\begin{array}{l}66.1 \\
66.4\end{array}$ & $\begin{array}{l}40.0 \\
36.0\end{array}$ & $\begin{array}{l}20.4 \\
19.8\end{array}$ & $\begin{array}{l}-2.0 \\
-2.0\end{array}$ & 909 \\
\hline
\end{tabular}

nisms causing patch formation. Patch occurrence as the function of patch spatial size has an exponential pattern. A similar one has been reported for zooplankton biomass in the surface layer from the northwestern part of the Indian Ocean (Goldberg \& Piontkovski 1985). The exponential pattern of occurrence in the heterogeneities is known for the surface temperature (Naumenko 1975). These types of heterogeneities in the structure of the physical fields are interpreted by hydrophysicists as the result of collapsing processes when large eddies are split into smaller and smaller ones on a scale ranging from hundreds of $\mathrm{km}$ to $\mathrm{cm}$ (Monin \& Ozmidov 1981). This collapse is caused by several hydrodynamic processes among which turbulence and internal waves play dominant roles. The fact that the trends in patchiness of total biomass are not different from those for a single species confirms the hydrophysical origin of these events.

In the eastern tropical Atlantic Ocean, where the amplitude of the internal waves reaches $20 \mathrm{~m}$ in the seasonal thermocline (Vladimirov et al. 1981), zooplankton biomass continuous records have been taken simultaneously with temperature measurements within the thermocline. In our initial hypothesis we assumed that the internal waves might considerably alter the zooplankton mesoscale heterogeneity in the surface layers. If this were considered in terms of the linear theory, then the internal waves (Miropolsky 1981) would produce coherence between temperature and zooplankton spectra peaks. Previous pure hydrophysical studies have indicated that the heterogeneities of a passive substance field in the upper layers might be induced by the horizontal components of velocity of the internal waves within the seasonal ther- mocline (Monin \& Piterbarg 1977, Krasitsky \& Monin 1985). From this point one might expect a correspondence in the temperature and plankton fields in the surface layers.

To test this hypothesis, theoretically expected wavelengths of energy spectra and temperature were determined from the data obtained from the buoy station (the region of Grid 22). Temperature fluctuations were continuously recorded over a period of $3 \mathrm{wk}$ at these stations. At a given Brunt-Väisälä frequency the theoretically expected wavelengths for the periods of 3,6 , 12 and $24 \mathrm{~h}$ were $18.0,37.4,76.3$ and $159.5 \mathrm{~km}$, respec tively. These values are quite similar to those in Table 2. It can be assumed that spatial heterogeneity of the temperature and zooplankton fields was formed by propagation of internal waves. It should be noted that the data on longer-term zooplankton sampling at drift stations with a frequency of 1 sample per hour over several days exhibits biomass spectral density peaks of zooplankton biomass with periods of 3 and $12 \mathrm{~h}$ (Piontkovski et al. 1985c). This situation enables us to interpret the oscillations of zooplankton biomass as a result of propagation of internal waves through the station.

In the above case, the mechanism of zooplankton patch formation could be attributed to the following According to the theory of the linear internal waves, the propagation of internal waves induces a direct shift and condensing of particles. The intensity of the shifting and condensing differs along the horizontal and vertical planes due to differences in latitudinal and longitudinal velocities of current speeds which cause the heterogeneity in spatial distribution of particles. In other words, the internal waves cause water currents 
in a given layer and, if the plankton is distributed nonuniformly, this could cause dilution or concentration of organisms in zones of convergence or divergence.

That the spatial spectral density functions decline with a slope of -2 to -3 is fairly well known for temperature (Boguslavsky et al. 1971, Krasnopevtsev \& Fedorov 1979) and for bioluminescent fields in the tropical regions (Urdenko 1974).

Kushnir et al. (1986) inferred parameters of the 2dimensional spatial heterogeneity of the bioluminescence field based on the equations of the linear theory of inertial-gravity waves and their measurements of temperature, current velocity and wind fluctuations. The bioluminescence measurements have been carried out along horizontal transects and vertical casts in the east tropical Atlantic. The observed bioluminescence fluctuations have been interpreted as a consequence of the inertial-gravity wave propagations. No significant differences between the theoretically expected spatial wavelength of the bioluminescence fluctuations (inferred from wave theory for a given region) and that from the field observations were noted. These results seems interesting in light of the discussion of our data, as the bioluminescent signal intensity in the oligotrophic regions of the eastern tropical Atlantic is formed mainly by the zooplankton fraction of the epipelagic community (Swift et al. 1983, $1985 a, b)$.

Fasham \& Pugh (1976) have obtained power spectra of temperature and chlorophyll in the eastern tropical Atlantic. The chlorophyll spectra had a power law slope of -2 at high wavenumbers and flattened to -1 at the lowest wavenumbers. This corresponded to the behaviour of a chlorophyll spectra predicted by the Denman-Platt model (Denman \& Platt 1976).

Other authors have tried to interpret mesoscale heterogeneity of plankton fields as the result of mesoscale turbulence. Gower et al. (1980) analysed data on chl a from remote sensing in terms of multiscale spatial heterogeneity of the phytoplankton field. The data analysis enabled the authors to approximate the variability in the phytoplankton field by the 2-dimensional spectral density function which declined with a spectra slope of -2 on a scale of several hundreds to tens of $\mathrm{km}$. The authors came to the conclusion that the phytoplankton field acts as a passive scalar field and its heterogeneity might be interpreted in terms of the turbulent processes theory. However, hydrophysicists note difficulties in distinguishing spectra of the turbulent and internal wave processes, which are strongly linked (Miropolsky 1981, Monin \& Ozmidov 1981).

The literature discussed above mainly deals with temperature and chlorophyll data which are also intensively analysed in the following overview papers: Fasham 1978a, b, Horwood 1978, Okubo 1980, and
Levin et al, 1993. Mesoscale analyses of zooplankton power spectra in the ocean are much less numerous. In 10 to $100 \mathrm{~km}$ transects taken in the North Sea, differences between chlorophyll and zooplankton spectra (data from a particle counter) have been reported (Mackas \& Boyd 1979). The chlorophyll spectrum had a shallower slope than that of the zooplankton abundance. This means that zooplankton forms a 'more finely grained pattern and suggest that they must have a stronger mechanism for formation of small-scale aggregations, or equivalently a better mechanism for resisting turbulent diffusion' (Mackas \& Boyd 1979).

In our data where temperature, chl $a$ and zooplankton power spectra have been measured simultaneously, the 3 parameters show similar spectrum slopes and average levels, i.e. they were not statistically distinguishable in terms of given confidence intervals. It should be noted also that in the case of zooplankton biomass power spectra one might expect a wide range in the slope of the curve because of changes in the zooplankton components, in terms of species and size variability. This should be mirrored in the summarised characteristics of the biomass spectrum, because different size groups of organisms can exhibit different power spectra. Such a situation has been reported from continuous records on particles in the coastal tropical waters of West Africa (Pugh, cited in Fasham 1978). Spectra of particles had a power law curve of -2 in the phytoplankton band but were more flattened (closer to -1) in the microzooplankton size range.

The mesoscale power spectra estimated for a single species (Neocalanus cristatus) from the subarctic north Pacific had a white-noise-like character (i.e. nil-slope), whereas simultaneously measured temperature and chlorophyll exhibited 'the classic' $-5 / 3$ slope spectra (Tsuda et al. 1993).

It should be stated, however, in our work of assessing the trends of mesoscale heterogeneity we are ignoring the effects of the interactions of the spatial and temporal components which influence total variability of a planktonic field. It is known that the amplitude of the diel trends of zooplankton biomass and abundance normally exceed the continuously recorded amplitudes of biomass or abundance observed along the horizontal transects on a scale of tens to hundreds of $\mathrm{km}$ in the tropical latitudes (Piontkovski \& Goldberg 1984).

It is suggested in future analysis of the variability in zooplankton biomass and abundance that the process of interaction of periodical and stochastic components should be considered. In terms of a rough model, the main periodical components are formed predominantly by biological factors, such as the diel vertical migrations, predator-prey interactions, etc., while the stochastic ones are governed mainly by physical factors, such as internal waves and turbulence. In statisti- 
cal terms, the turbulent diffusion could be responsible for the general trend of the declining spectra and its slope of -2 to -3 , while the internal waves of the inertial-gravity period are possibly, if they are well developed, responsible for the local spectra peaks observed on the background of these slopes.

Acknowledgements. This work has been supported by NASA grant No. NAG 5-3113. We are also grateful to our colleagues from the Institute of Biology of the Southern Seas and the Marine Hydrophysical Institute, Sevastopol, Ukraine, for their support with the background data on the buoy stations. It was a pleasure to work together on these long-term cruises in the ocean

\section{LITERATURE CITED}

Aiken J, Moore GF, Holligan P (1992) Remote sensing of oceanic biology in relation to global climate change. J Phycol 28:579-590

Alldredge AL, Robinson BH, Fleminger A, Torres JT, King MJ, Hamner WM (1984) Direct sampling and in situ observation of a persistent copepod aggregation in the mesopelagic zone of the Santa Barbara Basin. Mar Biol 80: $75-81$

Aron W (1958) The use of a large capacity portable pump for plankton sampling with notes on plankton patchiness. J Mar Res 16:158-173

Artamonov YuA, Polonski AV, Pereyaslavski MG (1987) Investigations of the water macroscale circulation in the north-western part of the eastern Atlantic. Deponent VINITI-392. Marine Hydrophysical Institute, Sevastopol (in Russian)

Boguslavsky SG, Vostroknutov AA, Lomanov YuP, Lubchenko VT (1971) Investigations of the temperature heterogeneities of the Atlantic Ocean surface. Morskie Gydrofizicheskie Issledovaniya (Mar Hydrophys Res) 4: 147-154 (in Russian)

Boyd CM (1973) Small-scale spatial patterns of marine zooplankton examined by an electronic in situ zooplankton detecting device. Neth J Sea Res 7:103-111

Bulgakov NP, Kushnir VM, Loshakin F, Mankovski BI (1991) Hydrological studies of the Caribbean Sea. Naukova Dumka, Kiev (in Russian)

Cassie RM (1963) Micro-distribution of plankton. Oceanogr Mar Biol Annu Rev 1:223-252

Cushing DH, Tungate DS (1963) Studies on a Calanus patch. I. The identification of a Calanus patch. J Mar Biol Assoc UK 43:327-337

De Decker AHB (1984) Near-surface copepod distribution in the South-western Indian and South-eastern Atlantic Ocean. Ann S Afr Mus 93(5):303-370

Denman KL, Platt $T$ (1976) The variance spectrum of phytoplankton in a turbulent ocean. J Mar Res 34:593-601

Fasham MJR (1978a) The statistical and mathematical analysis of plankton patchiness Oceanogr Mar Biol Annu Rev $16: 43-79$

Fasham MJR (1978b) The application of some stochastic processes to the study of plankton patchiness. In: Steele $\mathrm{JH}$ (ed) Spatial patterns in plankton communities. Plenum Press, New York, p 131-156

Fasham MJR, Pugh PR (1976) Observations on the horizontal coherence of chlorophyll a and temperature. Deep Sea Res 23:527-538
Gibbs CF (1979) Chlorophyll $b$ interference in the fluorimetric determination of chl a and 'phaeopigments' Aust J Mar Freshwat Res 30:597-606

Goldberg GA, Piontkovski SA (1985) Spatial-temporal structure of mesoplankton field of the Indian Ocean tropical zone superficial layer. Ekologiya Morya (Sea Ecol) 19: $86-110$ (in Russian)

Gower JFR, Denman KL, Holyer RJ (1980) Phytoplankton patchiness indicates the fluctuation spectrum of mesoscale oceanic structure. Nature 288:157-159

Greze VN, and 29 others (1984) Bioproduktsionnaya sistema krupnomaschtabnogo okeanicheskogo krygovorota. (The bio-productive system of the large-scale oceanic gyre). Naukova Dumka, Kiev (in Russian)

Hamner WM, Carleton JH (1979) Copepod swarms: attributes and role in coral reef ecosystems. Limnol Oceanogr 24: $1-14$

Haury L, McGowan JA, Wiebe PH (1978) Patterns and processes in the time-scales of plankton distributions. In: Steele JH (ed) Spatial patterns in plankton communities. Plenum Press, New York, p 277-328

Haury L, Pieper RE (1988) Zooplankton: scales of biological and physical events. In: Soule DF, Kleppel CS (eds) Marine organisms as indicators. Springer-Verlag, New York, p 35-73

Herman AW, Sameoto DD, Longhurst AR (1981) Vertical and horizontal distribution patterns of copepods near the shelf break south of Nova Scotia. J Fish Aquat Sci 38:1065-1076

Horne PW, Platt T (1984) The domunant space and time scales of variability in the physical and brological fields on continental shelves. Rapp PV Reun Cons Int Explor Mer 183: $8-19$

Horwood JW (1978) An analysis of the spatial heterogeneity of surface chlorophyll in one and two dimensions. J Mar Biol Assoc UK 58:487-502

IOC (1992) GOOS. Global Ocean Observing System, an initiative of the Intergovernmental Oceanographic Commission (of UNESCO). IOC, UNESCO, Paris

Konyaev KV (1981) Spektralnyi analiz slychainyih okeanalogicheskih polei. (The spectral analysis of the random oceanological fields). Hydrometeoizdat, Leningrad (in Russian).

Krasitsky VP, Monin AS (1985) Yavleniya na poverhnosti okeana. (The events on the ocean surface). Hydrometeoizdat, Leningrad (in Russian)

Krasnopevtsev AYu, Fedorov KN (1979) Heterogeneities pattern of temperature and salinity horizontal distribution in the upper layer of the ocean. Okeanologicheskie Issledovaniya (Oceanological Research) 30:82-86 (in Russian)

Kushnir VM, Tokarev YuN, Evstigneev PV (1986) The wave structure of the bioluminescence heterogeneities in the area of the tropical energy active polygon. Deponent VINITI-3440-V. Marine Hydrophysical Institute, Sevastopol (in Russian)

Lasker R (1976) Field criteria for survival of anchovy larvae: the relation between the inshore chlorophyll layers and successful first feeding. US Fish Bull 71:453-462

Lasker R, Zweifel J (1978) Growth and survival of first-feeding northern anchovy larvae (Engraulis mordax) in patches containing different proportions of large and small prey. In: Steele JH (ed) Spatial patterns in plankton communities. Plenum Press, New York, p 329-355

LeBrasseur RJ, Barraclough WE, Kennedy OD, Parsons TR (1969) Production studies in the strait of Georgia. Part III. Observations on the food of larval and juvenile fish in the Fraser River plume, February to May, 1967. J Exp Mar Biol Ecol 3:39-50 
Levin SA, Powell TM, Steele JH (1993) Patch dynamics. Springer-Verlag, Berlin

Longhurst AR (1981) Signıficance of spatial variability. In: Longhurst AR (ed) Analysis of marine ecosystems. Academic Press, London, p 415-442

Mackas DL, Boyd CM (1979) Spectral analysis of zooplankton spatial heterogeneity. Science 204, 4388:62-64

Mackas DL, Denman KL, Abbot MR (1985) Plankton patchiness: biology in the physical vernacular. Bull Mar Sci 37 $652-674$

Miller CB, Judkins DC (1981) Design of pumping systems for sampling zooplankton, with description of two-capacity sampler for coastal studies. Biol Oceanogr 1(1):29-56

Miropolsky YUZ (1981) Dynamics of the internal gravity waves in the ocean. Hydrometeoizdat, Leningrad (in Russian)

Monin AS, Ozmidov RV (1981) Okeanskaya turbulentnost. (Oceanic turbulence). Hydrometeoizdat, Leningrad, (in Russian)

Monin AS, Piterbarg SP (1977) On statistical description of the internal waves. Dokladyi Akademii Nauk SSSR (USSR Acad Sci Rep) 234(3):564-567 (in Russian)

Naumenko MF (1975) About the characteristics of the temperature field spatial heterogeneities of the ocean surface Morskie Gidrofizicheskie Issledovaniya (Mar Hydrophys Res) 2:96-107 (in Russian)

Okubo A (1980) Diffusion and ecological problems: mathematical models. Springer-Verlag, Berlin

Omori M Hamner WM (1982) Patchy distribution of zooplankton: behaviour, population assessment and sampling problems. Mar Biol 72:193-200

Ovchinnikov IM, Zats VI, Udodov AI (1985) The formation of the deepened eastern Mediterranean waters in the Adriatic Sea. Okeanoloiya (Oceanology) 25(6):911-917 (in Russian)

Piontkovski SA, Goldberg GA (1984) The ratio between spatial and temporal variability of plankton fields. Ekologiya (Ecology) 1:34-39 (in Russian)

Piontkovski SA, Minkina NI, Blinkov A, Popova EV (1985c) Spatial structure of zooplankton fields and internal waves of the tropical Atlantic. In: Eksperimentalnye Issledovaniya Tropicheskoi Atlantiki (Experimental studies of the tropical Atlantic). Deponent VINITI-4986-85. Marine Hydrophysical Institute, Sevastopol, p 207-221 (in Russian)

Piontkovski SA, Plotnikov VA, Melnık TA, Chistenko A (1985a) The elements of spatial structure of pelagic communities of quasi-homogeneous layer of the Indian Ocean. Pol Arch Hydrobiol 32:291-298

Piontkovski SA, Scherbatenko PV, Melnik TA (1985b)

This article was submitted to the editor
Spatial-temporal characteristics of horizontal and vertical zooplankton distribution in the Indian Ocean. Pol Arch Hydrobiol 32:310-318

Platt T, Caverhill C, Sathyendranath S (1991) Basin-scale estimates of oceanic primary production by remote sensing: the North Atlantic. J Geophys Res 96:15147-15159

Platt T, Denman KL (1975) Spectral analysis in ecology. Rev Ecol Syst 6(1):189-210

Plotnikov VA (1986) Thermohaline and dynamical structure of waters of the subequatorial regions of the Indian Ocean. In: Petipa TS (ed) Ekologicheskie sistemyl $v$ aktivnyih dinamicheskih raionah Indiiskogo Okeana (Ecological systems in the active dynamic regions of the Indian Ocean). Naukova Dumka, Kiev, p 18-40 (in Russian)

Polonksi AB, Goryachkin Yul, Kazakov Sl, Pereyaslavski MG (1985) The macroscale circulation of waters in the northwestern part of the tropical Atlantic. In: Eksperimentalnye Issledovaniya Tropicheskoi Atlantiki (Experimental Studies of the Tropical Atlantic). Deponent VINITI No. 4986-85, Marine Hydrophysical Institute, Sevastopol, p 26-37 (in Russian)

Steele JH (1978) Some comments on plankton patches. In: Steele JH (ed) Spatial patterns in plankton communities. Plenum Press, New York, p 1-17

Swift E. Biggley WH, Lessard EJ (1985b) Distributions of epipelagic bioluminescence in the Sargasso and Caribbean Seas. In: Zirino A (ed) Mapping strategies in chemical oceanography. Adv Chem Ser 209 Am Chem Soc, Washington, DC, p 235-258

Swift E, Biggley WH, Verity PG, Brown DT (1985a) Zooplankton are major sources of epipelagic bioluminescence in the Sargasso Sea and Gulf Stream. Bull Mar Sci 33:855-863

Swift E, Lessard EJ, Biggley WH (1985a) Organisms associated with stimulated epipelagic bioluminescence in the Sargasso Sea and Gulf Stream. J Plankton Res $7(6)$ : $831-863$

Tsuda A, Sugisaki H, Ishimaru T, Saino T, Sato T (1993) White-noise-like distribution of the oceanic copepod Neocalanus cristatus in the subarctic North Pacific. Mar Ecol Prog Ser 97:39-46

Urdenko VA (1974) Investigations of the bioluminescence light fields of the ocean. PhD dissertation Marine Hydrophysical Institute, Sevastopol (in Russian)

Vladimirov VL, Mankovsky VI, Martyinov OV (1981) Shortterm fluctuations of hydrooptical characteristics in the ocean photic zone and their link with the thermocline fluctuations. Oceanol 21:815-820

Wiebe PH (1970) Small-scale distrubution in oceanic zooplankton. Limnol Oceanogr 15(2):203-215

Manuscript first received: January 26, 1996

Revised version accepted: August 23, 1996 